\title{
Salman Rushdie's The Enchantress of Florence as History Reinvented
}

\section{https://doi.org/10.3126/litstud v29i01.39615}

\section{Tara Prasad Adhikari}

\begin{abstract}
The present paper focuses on how Rushdie blurs boundary between history and stories in his famous novel The Enchantress of Florence and what end does he achieve. Salman Rushdie's fascination with history becomes evident in his novel The Enchantress of Florence. It seems that Rushdie is truly handcuffed to history. In this novel, he has mixed history and legend in order to recreate new myths and histories. The novel chooses to combine myth and history, fact and fiction in order to liberate history from the shackles of positivism and re-invent it. This mixing of the real with the fictional and the fusion of the mythical with the historical has not only enriched his novels but has also opened up a new avenue for reading and writing history differently.
\end{abstract}

The Enchantress of Florence again proves that Rushdie is handcuffed to history. In this novel, he has mixed history and legend in order to recreate or reinvent new myths and histories. The novel chooses to combine myth and history, fact and fiction in order to liberate history from the shackles of cultural and political hegemony and re-invent it. This mixing of the real with the fictional and the incorporation of the mythical with the historic enriches the literariness of the text and opens the scope for the free play of reader's imagination. The story moves back and forth in time and space, blending fact and fiction, using myth and memories for the redefinition of truth itself.

The novel is set in the era of 16th century and the story revolves around a young Italian called Mogor dell Amore's visit to the Mughal emperor Akbar's court. Nicolle Vespucci, as the Florentine gentleman calls himself, claims to be a long lost relative, the uncle of Akbar, born of an exiled Mughal princess Qara $\mathrm{Koz}$ and a Florentine warrior Antonio Argalia. Basically a mix of imagination and reality, the book is populated with a large number of historical figures and incidents, all steeped in a fine fictional fabric.

Employing all the typical postmodern literary devices like irony, magic realism, parody, coupled with the theme of east and west and the search for a new world, the novel opens itself up for an alternative historical reality. Rushdie's principal aim in this mixing of myth and history is the renewal of the concept of history itself. He demands for the removal of the prejudices of historical objectivity.

Myth strengthens the fictionality of the text, whereas the historical accuracy justifies the claims of the objectivity of the text. In the words of A. S. Rao, "meanings and truths are influenced by their historical position and cannot in principle be set apart from history. The reality of a literary text lies with the reader's imagination" (64). The Enchantress of Florence gives emphasis to such imaginative world order.

Adopting a historiographical meta-fictional mode, knowingly disrupting chronology, introducing supernatural occurrences and obvious historically 
inaccurate elements, the novel reminds the reader that history is a relative construct, riddled with subjectivity. Padma Malini Sundararaghavan strongly supports the notion of fictionalized history when she says:

The myths crafted by empire, as also political myths of any era, have the ability to partially or wholly falsify, or shall we say fictionalize history as the facts themselves often suffer mutilation or erasure .Facts are obscured by propaganda, media manipulation and image- building experts who project a picture far removed from reality. (2)

The blurred boundary between fact and fiction is intensified in the novel through the presence of a character called Qara Koz. Who is Qara Koz and how she came to be the mistress of Argalia forms the central narrative that Niccolo Vespucci tells Akbar who has been completely ignorant of this hidden princess in the history of Mughals. The story of Qara Koz-Angelica, the lady black eyes, is an account that the foreigner Mogor del Amore narrates to Emperor Akbar to fill in the gaps in the history of the Mughals. The introduction of the myth of Qara $\mathrm{Koz}$ is a clear deviation from the traditional historical narratives. The narrator, who claims to be the son of this lost princess of the Mughal household, puts it"She was a princess of the true Chaghatrai blood, a direct descendent of Genghis khan, a member of the house of Timur, and the sister of the first Mughal Emperor of India, whom she called the Beaver" (166). The narrator Niccolo Vespucci goes on to narrate the story of his mother and claims that "her name was Angelica and she was, a Mughal princess, and the most beautiful woman anyone had ever seen, and an enchantress without compare, a mistress of potions and spells of whose powers all were afraid" (167).

Thus this wondrous beauty's adventures in the Middle East and Florence, as she conquers the heart of one bloody conqueror after another, becomes the core of the novel. She is every man's lubricious dream, at once princess, slave and witch, and willing to do whatever it takes to please her current lord and to survive. Rushdie draws the character of Qara Koz on the magic realist lines by juxtaposing the sharply rendered and detailed elements, in the foreground and background, to develop an atmosphere of mystery and ambiguity. Her extraordinary beauty that makes men fall in love with her, and the magical powers that she uses to enchant others, render the ordinary unfamiliar and magical, thus blurring the line between fact and fantasy. With these dreams of Akbar and the subsequent clarifications provided by Qara $\mathrm{Koz}$, the mystery around the foreigner and his ancestry is solved to some extent and all the strands of the story are united. The narrator, who is endowed with a fractured and faulty vision of his ancestry and identity, reshapes his history through the imaginative reconstruction of the past. Thus through the imagination of the narrator, history of Mugal emperors becomes clearer.

In the novel, the Characters from east are chronologically intertwined with characters from western world, along with their culture and religion that they signify. The encounter between Akbar and the Mogor is a literal manifestation of the connection between East and West, one of the novel's thematic strands. Rushdie, like Garcia-Marquez, intertwines actual historical characters and events within a story full of magical realism and fantasy.

In this novel Rushdie has mixed history with fiction in order to create a tale of adventure, power and romance. History and myth coexist when the hidden 
Mughal princess and the enchantress Qara Koz meets Niccolo Machiavelli, and when Argalia battles Vlad the Impaler, Dracula. One constantly questions which details are true and which are products of Rushdie's extraordinary imagination Akbar's favorite wife Jodha is a product of his imagination, an imaginary wife dreamed up by Akbar .That imagination is so strong that she becomes real, at least until Akbar's intense love for her diminishes. This is a sheer portrayal of the ultimate male fantasy, as well as an expression of the way in which imagination becomes real.

Rushdie mixes reality and fantasy in such a way that one no longer knows where the dream world ends and the real world begins. The episode of the painter Dashwant painting Qara Koz into life and himself vanishing as an imaginary being "in the margins of history"(190) is a typical example of the disruption of border lines between real and unreal, life and art. In many ways, The Enchantress of Florence is a story about the story, a meta-fiction that looks at the line between invention and reality and crosses it.

Thus Rushdie, in The Enchantress of Florence, reimagines and reinvents history weaving it with fantasy, memory, tradition and other cultural artifacts.

\section{Works Cited}

Rao, A.S. Myth and History in Contemporary Indian Novel in English. Delhi: Atlantic Publishers, 2000.

Rushdie, Salman. The Enchantress of Florence. London: Jonathan Cape, 2008.

Sundararaghavan, Padma Malini. Fictionalising Myth and History: A Study of Four Postcolonial Novels. New Delhi: Orient Black Swan, 2013. 